\title{
A Load Forecasting Analysis Method Considering Multiple Demand Side Resources
}

\author{
Zhou Long $^{1}$, Liu Dunnan ${ }^{2}$, Xiao Zhanhui ${ }^{1}$, Wang Qiang ${ }^{2}$ \\ 1Guangdong Power Grid Corporation, Guangzhou City 510600, P.R. China \\ 2North China Electric Power University, Beijing 102206, P.R. China
}

\begin{abstract}
Load forecasting plays an important part in power grid planning of grid company, this paper focus on the new load forecasting method under the effect of demand side resources, the potentials of all kinds of demand side resources are estimated by statistics method within a substation area to make the load forecasting more accurate, and to avoid the investment waste caused by extensive expansion program.
\end{abstract}

\section{Introduction}

Load forecasting plays an important part in power grid planning of grid company, under the new circumstance, the grid company will face more severe challenges when they perform above responsibilities [1]: On the one hand, the future electricity demands will increase further, which puts forward new expansion requirements to the power supply side; on the other hand, the power grid expansion face with multiple constraint factors such as land and capital, which make the power grid planning landing is difficult. Therefore, in today that expansion of the supply side resources faces numerous bottlenecks, the discovery of new demand side resources is the new way to mitigate the above bottlenecks.

Before that some scholars had already studied on load forecasting method, Niu Dongxiao and Zhao Lei had proposed the application of PSO Grey Model in power load forecasting [2]; In the application of neural network theory, Bahman Kermanshahi had used GDP, GNP, electricity, oil and other 10 non-load variables for longterm load forecasting in Japan [3]. Most scholars above used models to consider load forecasting problem, and most research was conducted on the load forecasting accuracy, which can not achieve the effect of saving supply side resources.

This paper focus on the new load forecasting method under the effect of demand side resources, different from the traditional method, the basic idea and purpose of this method is to estimate the potentials of all kinds of demand side resources within a substation area by statistics method, and take that potentials into load forecasting process to make the load forecasting more accurate, and to avoid the investment waste caused by extensive expansion program [4].

\section{The maximum load modeling analysis based on multivariate demand side resources}

The basic idea of load forecasting model compatible with demand side resources, is to consider the coverage area of a substation as an object, define every user on each electricity transmission line, analyze all kinds of users in the coverage area, and calculate affects that demand side resources influence on maximum load of all types of users. The general idea figure of load forecasting method compatible with demand side resources is shown as figure1.

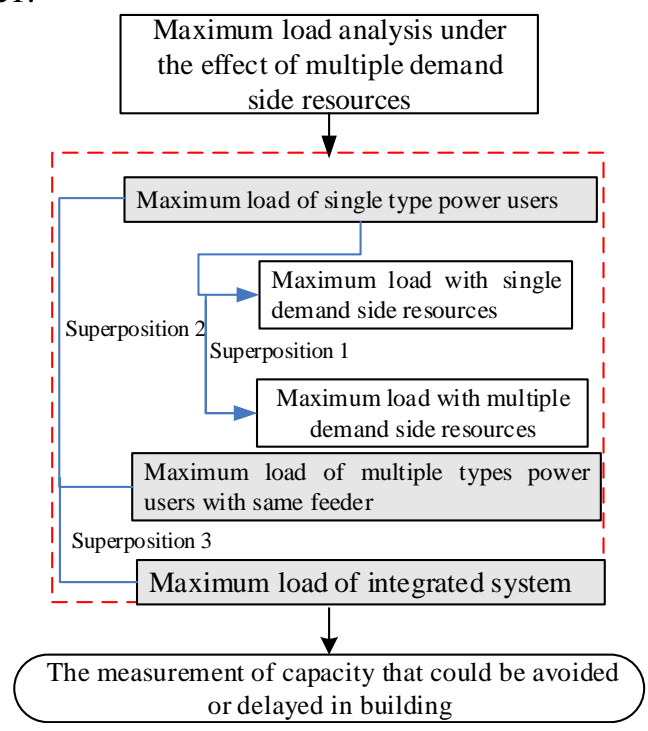

Figure 1 The general idea figure of load forecasting method compatible with demand side resources

\subsection{The solution of single type of power users' maximum load}

Every kind of electricity user has multiple power link, such as residential user's main power link including lighting, air conditioners, refrigerators, water heaters, etc [5]. Begin from the simplest situation, first studying the maximum load forecasting model that considering single demand side resources. The maximum load forecasting formula of some kind of users considering single demand side resources (i.e. the user has only one electricity link, and there is only one energy efficiency resource and one load resource) is as shown in type 1 :

$$
P_{\max , D S M}=Q_{0, p r e} *\left(1-\alpha_{E E}\right) * \frac{1}{t} * \frac{1}{\beta_{L D}}
$$

In the formula, $P_{\max }$ DSM represents the prediction result of maximum load under the effect of demand side resources, $\mathrm{kW} ; \alpha_{E E}$ represents the consumption reduction rate of this type of users under the effect of energy efficiency resources; $\beta_{L D}$ represents the load rate of this type of users under the effect of load resources. 


\subsection{The load forecasting considering multiple demand side resources}

The analysis of multiple energy efficiency resources

First, considering the change of total electricity consumption under the effect of multiple energy efficiency resources. Due to the energy efficiency resources refer to the technical measures adopted by power users, directly corresponding to a particular power type (such as energy-saving refrigerators, energy-saving air-conditioning, etc.), and consumption reduction rate is relative to the original electricity link type, not the overall electricity situation. Therefore, the electricity saving effect of energy efficiency resources is calculated in accordance with the power type.

Assume that $\Delta Q$ is the amount of electricity saving, $\Delta Q_{i}$ represents the amount of electricity saving in $i$-th power link, $Q_{i, 0}$ represents initial electricity consumption of predict year in $i$-th power link, $\alpha_{E E, i}$ is the consumption reduction rate of those particular users under the effect of energy efficiency resources in $i$-th power link, $\lambda_{i}$ is the state coefficient that determine whether the energy efficiency resources exist, when the value of $\lambda_{i}$ is 0 , indicating that users do not have those resources; when the value of $\lambda_{i}$ is 1 , indicating that users have those resources.

The amount of electricity saving of this type of users under the effect of energy efficiency resources can be expressed as:

$$
\Delta Q_{i}=Q_{i, 0} * \lambda_{i} * \alpha_{E E, i}
$$

Under the effect of multiple energy efficiency resources, the total amount of electricity saving is the sum of electricity saving in each power link, that is

$$
\Delta Q=\Delta Q_{1}+\Delta Q_{2}+\cdots+\Delta Q_{i}+\cdots+\Delta Q_{k}
$$

In the formula, $k$ represents the number of power links of this electricity user.

Therefore, the electricity consumption $Q_{E E}$ under the effect of energy efficiency resources is:

$$
Q_{E E}=Q_{0, p r e}-\Delta Q
$$

The analysis of multiple load resources

Due to the electricity saving index of load resources is load rate, load rate is a concept relative to the overall electricity situation, and it can not be allocated to the various electricity link, therefore, the electricity saving potential of load resources is calculated in accordance with its types. First of all, the formula of reduced maximum load under the effect of single load resources is:

$$
\begin{array}{r}
\Delta P_{\max , i}=\left\{\begin{array}{rr}
P_{\max , E E}-Q_{E E} * \lambda_{i} * \frac{1}{\beta_{L D, i}} * \frac{1}{t} & \lambda_{i}=1 \\
0 & \lambda_{i}=0
\end{array}\right. \\
P_{\text {max }, E E}=\frac{\mathrm{Q}_{E E}}{\beta_{0} * t}
\end{array}
$$

In the formula, $\Delta P_{\max , i}$ represents the reduced maximum load under the effect of $i$-th load resources, $\mathrm{kW} ; P_{\max , E E}$ represents the maximum load under the effect of energy efficiency resources, $\mathrm{kW} ; \beta_{L D,}{ }_{i}$ is the load rate of this power user under the effect of $i$-th load resources.

The reduced maximum load under the effect of multiple load resources is:

$$
\Delta P_{\max }=\left(\begin{array}{l}
\Delta P_{\max , 1}+\Delta P_{\max , 2}+\cdots+\Delta P_{\max , i} \\
+\cdots+\Delta P_{\max , w}
\end{array}\right) * \zeta_{1}
$$

In the formula, $w$ represents the number of load resources that this user has.

Due to the load resources will not have effect at the same time, the formula (7) introduce the load coincidence factor $\zeta_{1}$.

Therefore, the predict result of maximum load under the effect of demand side resources is:

$$
P_{\max }, D S M=P_{\max , E E}-\Delta P_{\max }
$$

\subsection{The solution of multiple type of power users' maximum load with same feeder}

On the basis of calculated maximum load of single type of power users, this section will further measure the maximum load of multiple type of users with same feeder. Suppose $P_{\max , i j}$ is the maximum load of $j$-type power users in $i$-th transmission line under the effect of demand side resources, then the superimposed benefits of all users in $i$-th transmission line are:

$$
P_{\max , i}=\left(\sum_{j=1}^{m} P_{\max , i j}\right) * \zeta_{2}
$$

In the formula, $m$ represents the number of power users classification; $P_{\max , i}$ is the maximum load of the $i$ th transmission line's coverage area, $\mathrm{kW} ; \zeta_{2}$ represents load coincidence factor, to adjust the maximum load of different users in same feeder.

\subsection{The solution of integrated maximum load}

Since the substation covers multiple lines, the electricity situation of each line need to be considered when solving the integrated maximum load, and then superimpose the electricity, the superimposed effect is:

$$
\begin{aligned}
& U P_{\max , D S M}=\sum_{i=1}^{n} P_{\max , i} \\
& =\left[\sum_{i=1}^{n}\left(\sum_{j=1}^{m} P_{\max , i j}\right) * \zeta_{2}\right] * \zeta_{3}
\end{aligned}
$$

In the formula, $U P_{\max , D S M}$ represents integrated maximum load, $\mathrm{kW} ; \zeta_{3}$ is load coincidence factor, to adjust the maximum load between different feeders; $n$ is the number of transmission lines of this substation. 
Thus, the substation capacity that could be delayed in building can be calculated through the change of maximum load under the effect of demand side resources before and after, it is as shown in formula (11).

$$
\Delta R=R_{0}-R=\eta *\left(P_{\max , 0}-U P_{\max , D S M}\right)
$$

In the formula, $\Delta R$ represents the substation capacity could be avoided or delayed in building after considering demand side resources, $\mathrm{kVA}$.
In this paper, simulation is the electricity situation of an area with $220 \mathrm{kV}$ substation, and assuming that all kinds of users did not introduce any demand side resources before the simulation period, on the basis of defining user's type of each line, analyzing each user's primary electricity sector, calculating its electricity saving and load reduction result under the effect of energy efficiency resources and load resources, to predict the maximum monthly load of this area in next five years under the effect of demand side resources or not.

\section{Model simulation}

Table 1(a) The predict results of line 1 under the effect of demand side resources Time: month

\begin{tabular}{|c|c|c|c|c|c|}
\hline \multicolumn{2}{|c|}{ Users' type } & $\begin{array}{l}\text { Electricity } \\
\text { consumption under } \\
\text { the effect of energy } \\
\text { efficiency resources } \\
\text { (ten thousand } \mathrm{kWh} \text { ) }\end{array}$ & $\begin{array}{l}\text { Maximum load under the effect } \\
\text { of energy efficiency resources } \\
\text { (ten thousand kWh) }\end{array}$ & $\begin{array}{l}\text { Reduced maximum } \\
\text { load under the effect } \\
\text { of load resources } \\
\text { (ten thousand kWh) }\end{array}$ & $\begin{array}{l}\text { Maximum load under } \\
\text { the effect of demand } \\
\text { side resources (ten } \\
\text { thousand } \mathrm{kWh} \text { ) }\end{array}$ \\
\hline \multicolumn{2}{|c|}{ Residential users } & 1179.734 & 2.731 & 0.473 & 2.447 \\
\hline \multirow{2}{*}{$\begin{array}{l}\text { Industrial } \\
\text { users }\end{array}$} & $\begin{array}{c}\text { Light } \\
\text { industry }\end{array}$ & 112.043 & 0.259 & 0.057 & 0.225 \\
\hline & $\begin{array}{c}\text { Heavy } \\
\text { industry }\end{array}$ & 508.095 & 1.176 & 0.274 & 1.012 \\
\hline \multirow{3}{*}{$\begin{array}{l}\text { Business } \\
\text { users }\end{array}$} & Hotel & 176.794 & 0.409 & 0.046 & 0.382 \\
\hline & $\begin{array}{c}\text { Shopping } \\
\text { mall }\end{array}$ & 222.870 & 0.516 & 0.066 & 0.476 \\
\hline & Office & 175.831 & 0.407 & 0.065 & 0.368 \\
\hline \multirow{3}{*}{$\begin{array}{l}\text { Other } \\
\text { users }\end{array}$} & $\begin{array}{l}\text { Research } \\
\text { institute }\end{array}$ & 119.858 & 0.277 & 0.048 & 0.249 \\
\hline & Organ & 190.689 & 0.441 & 0.097 & 0.383 \\
\hline & Hospital & 176.247 & 0.408 & 0.071 & 0.366 \\
\hline
\end{tabular}

Table 1(b) The predict results of line 2 under the effect of demand side resources Time: month

\begin{tabular}{|c|c|c|c|c|c|}
\hline \multicolumn{2}{|c|}{ Users' type } & $\begin{array}{l}\text { Electricity } \\
\text { consumption under } \\
\text { the effect of energy } \\
\text { efficiency resources } \\
\text { (ten thousand kWh) }\end{array}$ & $\begin{array}{l}\text { Maximum load under } \\
\text { the effect of energy } \\
\text { efficiency resources } \\
\text { (ten thousand } \mathrm{kWh} \text { ) }\end{array}$ & $\begin{array}{l}\text { Reduced maximum load } \\
\text { under the effect of load } \\
\text { resources (ten thousand } \\
\text { kWh) }\end{array}$ & $\begin{array}{l}\text { Maximum load under the } \\
\text { effect of demand side } \\
\text { resources (ten thousand } \\
\text { kWh) }\end{array}$ \\
\hline \multicolumn{2}{|c|}{ Residential users } & 1216.88 & 2.817 & 0.573 & 2.473 \\
\hline \multirow{2}{*}{$\begin{array}{c}\text { Industrial } \\
\text { users }\end{array}$} & $\begin{array}{c}\text { Light } \\
\text { industry }\end{array}$ & 135.138 & 0.313 & 0.082 & 0.264 \\
\hline & $\begin{array}{c}\text { Heavy } \\
\text { industry }\end{array}$ & 458.438 & 1.061 & 0.248 & 0.913 \\
\hline \multirow{3}{*}{$\begin{array}{c}\text { Business } \\
\text { users }\end{array}$} & Hotel & 192.678 & 0.446 & 0.097 & 0.388 \\
\hline & $\begin{array}{c}\text { Shopping } \\
\text { mall }\end{array}$ & 191.826 & 0.444 & 0.096 & 0.386 \\
\hline & Office & 185.153 & 0.429 & 0.094 & 0.372 \\
\hline \multirow{3}{*}{$\begin{array}{l}\text { Other } \\
\text { users }\end{array}$} & $\begin{array}{l}\text { Research } \\
\text { institute }\end{array}$ & 134.537 & 0.311 & 0.059 & 0.276 \\
\hline & Organ & 173.452 & 0.402 & 0.110 & 0.335 \\
\hline & Hospital & 201.666 & 0.467 & 0.102 & 0.405 \\
\hline
\end{tabular}


Table 2 The comparative analysis of maximum load before and after under the effect of demand side resources

\begin{tabular}{|c|c|c|c|c|c|}
\hline $\begin{array}{l}\text { Line } \\
\text { number }\end{array}$ & $\begin{array}{c}\text { Initial } \\
\text { maximum load } \\
\text { (ten thousand } \\
\text { kW) }\end{array}$ & $\begin{array}{l}\text { Maximum load } \\
\text { without considering } \\
\text { the effect of demand } \\
\text { side resources (ten } \\
\text { thousand } \mathrm{kW} \text { ) }\end{array}$ & $\begin{array}{l}\text { Maximum load } \\
\text { under the effect of } \\
\text { demand side } \\
\text { resources (ten } \\
\text { thousand } \mathrm{kW} \text { ) }\end{array}$ & $\begin{array}{l}\text { Reduction rate of } \\
\text { maximum load }\end{array}$ & $\begin{array}{l}\text { The substation } \\
\text { capacity could be } \\
\text { delayed in building } \\
\text { (ten thousand kVA) }\end{array}$ \\
\hline 1 & 3.082 & 4.379 & 3.544 & $23.56 \%$ & \\
\hline 2 & 3.147 & 4.470 & 3.487 & $28.19 \%$ & 1.524 \\
\hline 3 & 3.240 & 4.839 & 3.775 & $28.18 \%$ & \\
\hline
\end{tabular}

The above table (table1 (a), table1 (b), table (2)) shows that in the comparative analysis of having demand side resources (energy efficiency resources and load resources) or not, the maximum load of power users in three lines has shown obvious downtrend, and the decline ratio has reached 20 percent or more. Also, the substation capacity could be delayed in building is $15,240 \mathrm{kVA}$. It can be seen that demand side resources not only bring lower user costs, but also improve the power supply reliability level of the system.

\section{Conclusion}

This paper presents a new load forecasting method compatible with demand side resources, which focuses on analyzing the impact of demand side resources on load forecasting, and this whole new load forecasting method doing quantitative analysis by establishing a mathematical model. The numerical example analysis shows that the new load forecasting method compatible with demand side resources allows power users' maximum load decreased obviously, and it has declined by up to 20 percent, the substation capacity can be delayed in building is 15,240 kVA. Therefore, demand side resources not only bring lower user costs, but also improve the power supply reliability level of the system.

\section{References}

[1] He-Rui Cui; Wci Li; Bo Zhang; A Long-term forecasting Model Based on Grey Feed-Back Modification [C] Machine Learning and Cybernetics, 2006 International Conference on 2006,8:413-416.

[2] Niu Dong-xiao, Zhao Lei, Zhang Bo, Wang Hai feng. The Application of Particle Swarm Optimization Based Grey Model to Power Load Forecasting [J]. Chinese Journal of Management Science,2007, 15 (1) :69-73

[3] Bahman Kermanshah, H I.Up to year 2020 load forecasting using neural nets[J].Electric Power and Energy Systems, 2002,24(9):789-797.

[4] WANG Beibei, LI Yang. Demand side management planningand implementation mechanism for smart grid $[\mathrm{J}]$. Electric PowerAutomation Equipment, 2010,30 (12): 19-24.
[5] Kennedy J. , Eberhart R. C. . Particle swarm optimiza-tion[ C] . Proc. IEEE Int. Conf. Neural Networks. Pisca-taway, NJ: IEEE Press, 1995: 19421948. 